\title{
LUT
}

University

Innovation capability for SME success: perspectives of financial and operational performance

\author{
Saunila Minna
}

This is a Post-print

version of a publication

published by Emerald Group Publishing

in Journal of Advances in Management Research

DOI: $10.1108 / J A M R-11-2013-0063$

Copyright of the original publication: (C) 2014, Emerald Group Publishing

Please cite the publication as follows:

Saunila, M. (2014). Innovation capability for SME success: perspectives of financial and operational performance. Journal of Advances in Management Research, vol. 11, issue 2. pp. 163-175. DOI: 10.1108/JAMR-11-2013-0063

This is a parallel published version of an original publication.

This version can differ from the original published article. 


\section{INNOVATION CAPABILITY FOR SME SUCCESS: PERSPECTIVES OF FINANCIAL AND OPERATIONAL PERFORMANCE}

\section{Structured abstract}

Purpose - The relationship between overall innovation and innovation capability, and performance has been a topic of several earlier studies. However, the effects of the aspects of innovation capability on performance of a firm have stayed unfamiliar. The objective of this research is to study the relationship between organizational innovation capability and firm performance. The study contributes to the current understanding by presenting the important aspects of organizational innovation capability that affect firm performance. The effects are studied to both financial and operational performance.

Design/methodology/approach - The approach of this study is quantitative. The data used to test the hypotheses was gathered from Finnish SMEs with a web-based questionnaire. The sample covered 2400 SMEs employing 11-249 persons and having a revenue of 2-50 Meuro. The sample was randomly selected.

Findings - The findings showed that three aspects of innovation capability, namely ideation and organizing structures, participatory leadership culture, and know-how development, has some effect on different aspects of firm performance. Surprisingly, the aspects of innovation capability were found to be more influential to the financial performance than operational performance.

Practical implications - The paper contains suggestions for improving performance through developing innovation capability. The paper aims to support practice in two ways. First, organizations can identify aspects of innovation capability that affect operational and financial performance. In that way, organizations can benefit the results by applying these aspects in their everyday operations. Second, the results of the paper may help professionals to begin to understand that leveraging innovation capability may improve an organization's performance.

Originality/value - Previous research has often either concentrated on innovation capability as a one dimension without studying the relationship aspect by aspect or studying only the effects of one aspect of innovation capability. The results of the study take one step further by investigating the relationship of multiple aspects of innovation capability and firm performance.

Keywords - Innovation capability, Performance, Financial performance, Operational performance, SME 
Saunila, M. (2014). Innovation capability for SME success: perspectives of financial and operational performance. Journal of Advances in Management Research, 11(2), 163-175.

Publisher: Emerald Group Publishing Limited 
Saunila, M. (2014). Innovation capability for SME success: perspectives of financial and operational performance. Journal of Advances in Management Research, 11(2), 163-175.

\section{Introduction}

Nowadays, when organizations operate in very challenging environments, developing innovation capability is vital. Innovation implies the adoption of a new idea or behavior (Jiménez-Jiménez and Sanz-Valle, 2011). The study of Dobni (2010) concludes that firms that possess high innovation orientations engage in value creation strategies, for example, developing new products/services. Innovation can be regarded as an organizational capability, because it is an act that deploys resources with a new ability to create value (Yang et al., 2006). Therefore, developing innovation capability is important, as innovation plays a key role in the survival and growth of organizations (Francis and Bessant, 2005).

Innovation capability has been suggested to be a multi-faceted construct. The categories used in the area of innovation capability often adopt a certain type of innovation, such as product innovation or process innovation, instead of the overall innovation capability (Ibrahim et al., 2009). Innovation capability has been divided into radical and incremental innovation capability (Sen and Egelhoff, 2000). The effects of innovation capability to firm performance have usually been studied by using the previously mentioned categories. According to Rosenbusch et al. (2011) only focusing on delivering innovative offerings to the market place might not fully leverage the potential of innovation. Small and medium sized enterprises (SME) can benefit even more if they develop, communicate, and embrace an innovation orientation. The empirical studies that discuss the organizational innovation capability (i.e. the aspects that affect managing innovation) as a whole and its impacts are rare. Thus, the question that have remained unsolved is does the individual aspects of innovation capability together have an impact on the performance of a firm.

The objective of this research is to study the relationship between organizational innovation capability and firm performance. The study contributes to the current understanding by presenting the important aspects of organizational innovation capability that affect firm performance. The effects are studied to both financial and operational performance. Previous research has often either concentrated on innovation capability as a one dimension without studying the relationship aspect by aspect or studying only the effects of one aspect of innovation capability. Therefore, the results of the study take one step further by investigating the relationship of multiple aspects of innovation capability and firm performance. The results contribute to the existing discussion on innovation capability - performance relationship by diminishing the gap between theory and practice and by building requisites for further research.

\section{Literature review}

\subsection{Innovation and performance}


Saunila, M. (2014). Innovation capability for SME success: perspectives of financial and operational performance. Journal of Advances in Management Research, 11(2), 163-175.

According to Calantone et al. (2002) innovation is the most important determinant of an organization's performance. Tidd (2001) divides measures that are used to prove the relationship between innovation and business performance, into two categories. The first group concerns accounting and financial performance. These measures include profitability, return on investment and share price. The second group concerns market performance, for example the share or growth (Tidd, 2001). Several studies have examined the relationship between innovation and firm performance (Calantone et al., 2002; Cainelli et al., 2004; Keskin, 2006; Bowen et al., 2010; Jiménez-Jiménez and Sanz-Valle, 2011) and supported to the idea that innovation is a key driver of firm success.

The effects of different types of innovations have been studied in earlier literature. Subramanian and Nilakanta (1996) found that different kind of innovations have an impact on different fields of performance. Organizational innovations improve coordination and cooperation in the organization, and they have been indicated as better results in efficiency measures. Technical innovations improve the organization's competitiveness, and they have been shown to have a positive impact on the results of effectiveness measures (Subramanian and Nilakanta, 1996). According to Gopalakrishnan (2000), the speed and innovation magnitude are linked to the results of different measures of performance. Innovation speed has a strong impact on financial performance, measured by the average return on assets. However, innovation speed is not associated with executives' perceptions of overall performance. Innovation magnitude is associated with executives' positive perceptions of overall performance even though it does not have a significant impact on financial performance (Gopalakrishnan, 2000). On the other hand, Varadarajan (2009) points out that not only radical innovations but incremental innovations are critical for the survival, growth, and profitability of organizations. On the basis of earlier literature, Armbruster et al. (2008) have shown that organizational innovations act as prerequisites and facilitators of an efficient use of technical product and process innovations, and therefore they are sources of competitive advantage. Organizational innovations themselves have impact on business performance with regard to productivity, lead times, quality and flexibility (Armbruster et al., 2008).

As presented earlier, the relationship between overall innovation and performance has been a topic of several earlier studies. However, the effects of the innovation capability on performance of a firm have stayed unfamiliar. Previously, the majority of studies used R\&D expenditure as the principal innovation measure. However, R\&D expenditure suffers from several shortcomings when used as an innovation measure. For example, the tendency towards the understatement of R\&D in smaller firms limits the applicability of such a measure to capture the state of innovation. This has resulted in a new generation of research that studies the effect of innovation on firm performance by focusing on the complexities of innovation as a process and channels through which the inputs of innovation, namely innovation capabilities, are transformed into better performance (Hashi and Stojcic, 2013). Some individual aspects and their relationship to performance have been studied but there is a lack of studies 
Saunila, M. (2014). Innovation capability for SME success: perspectives of financial and operational performance. Journal of Advances in Management Research, 11(2), 163-175.

concentrating on the aspects of innovation capability as a whole for achieving higher performance. First it is however described more detailed what is referred when used the term innovation capability.

\subsection{Innovation capability}

Innovation capability has been suggested to be a multi-faceted construct. There is no common way of analysis by which to study it, due to the variety of perspectives of innovation management (Perdomo-Ortiz et al., 2006). According to Neely et al. (2001), an organization's innovation capability can be described as its potential to generate innovative outputs. Similarly, Lawson and Samson (2001), consider innovation capability as a theoretical framework aiming to describe the actions that can be taken to improve the success of innovation activities. Prajogo and Ahmed (2006) discuss the technological factors of innovation management and human factors of innovation management. Human factors include the people and social practices as ingredients in organizational success. Martínez-Román et al. (2011) divide innovation capability in three dimensional factors: knowledge, organization and human factor. PerdomoOrtiz et al. (2006) have used a term business innovation capability to describe the critical success factors of innovation processes. These critical factors can be interpreted as business innovation capability dimensions, and the capability can be measured with the factors.

Some studies point out the organizational aspects of innovation. A body of literature has identified the common factors shared by innovative organizations and the factors that impact on the ability to manage innovation (Lawson and Samson, 2001; Perdomo-Ortiz et al., 2006; Martensen et al., 2007; Smith et al. 2008; Kallio et al., 2012; Saunila and Ukko, 2011). Similarly, in this study, innovation capability is defined to consist of the aspects influencing an organization's capability to manage innovation. In accordance with the earlier literature and the previous study of Saunila and Ukko (2011), innovation capability has been divided into seven aspects in this study: participatory leadership culture, ideation and organizing structures, work climate and wellbeing, know-how development, regeneration, external knowledge, and individual activity. A description of each aspect is presented next.

\section{Participatory leadership culture}

Participatory leadership culture refers to the overall atmosphere of the organization that supports and motivates innovation, and leadership that facilitates innovation. The ability to lead, direct and support the creation and sustaining of innovation behaviors is important for a firm (Bessant, 2003). Therefore, it is important that managers invest time in increasing the personnel's opportunities to participate in development activities (Lampikoski and Emden, 1999), as well as strike a balance that allows the employees to act on good ideas (Dobni, 2008). Today, leadership is seen as a skill to direct the employees' energy towards the right direction instead of giving orders and instructions (Lampikoski and Emden, 1999). The management style is connected to the culture of the firm, which plays an important role in motivating the 
Saunila, M. (2014). Innovation capability for SME success: perspectives of financial and operational performance. Journal of Advances in Management Research, 11(2), 163-175.

employees. Innovation capability requires a collaborative, open culture and incentives that reward challenging current actions (Skarzynski and Gibson, 2008).

Work climate and wellbeing

Work climate and well-being aspect represent the wellbeing of the employees and further the work climate for innovation development, including collaboration and values. Innovation is more likely in a situation where people attribute high levels of integrity, competence, reliability, loyalty and openness to others and view others as equals. Creating this environment involves having employees understand their roles, and then further developing their creative and independent sides (Dobni, 2008). An employee's motivation is connected to his/her wellbeing and experience as a member of the work community (Viitala, 2005). According to McMurray et al. (2010), leaders who demonstrate empowering behaviors enhance the employees' wellbeing. Favorable conditions require that the employees are treated equally (Dobni, 2008).

\section{Ideation and organizing structures}

Ideation and organizing structures is related to the structures and systems that successful innovation requires. This includes the generation, development and implementation of innovations, and the ways how the work tasks of the organization are organized. Bessant (2003) highlights the importance of the ability to create consistency between innovation values and behavior and the organizational context (structures, procedures etc.), as well as the ability to move innovative activity across organizational boundaries. Therefore, innovation requires supporting tools to enable an idea generation pipeline (Skarzynski and Gibson, 2008). According to Subramanian and Nilakanta (1996), decentralized and informal organizational structures facilitate innovations. They also propose that flexibility and openness of structures help to encourage new idea generation. A supportive structure plays an important role in improving communication in the organization (Dixit and Nanda 2011). Reward systems are powerful motivators and foster creative behavior (Lawson and Samson, 2001).

\section{Know-how development}

Know-how development aspect includes skills and knowledge of the employees that play an important role in innovation capability. This includes the utilization of knowledge as well as the improvement of employee skills. An organization committed to learning and development seeks a full understanding of its environment, including the customers, competitors, and emerging technology (Calantone et al. 2002; Keskin, 2006). Tidd et al. (2005) state that an innovative organization involves key individuals, as well as continuing and stretching individual development.

\section{External knowledge}

An external knowledge aspect highlights the importance of the proper behavior of exploiting external networks and knowledge to the overall organizational innovation capability. According to Swink (2006), the firm's ability to collaborate externally is a key to its innovative 
Saunila, M. (2014). Innovation capability for SME success: perspectives of financial and operational performance. Journal of Advances in Management Research, 11(2), 163-175.

success. The strength of inter-firm relationships influences the extent of tacit knowledge transfer, and the tacit knowledge obtained from partner firms affects a firm's innovation capability (Cavusgil et al., 2003). Interaction with suppliers, customers, industry associations, competitors and the like can provide missing external inputs that the organization itself cannot provide (Lawson and Samson, 2001; Romijn and Albaladejo, 2002).

\section{Regeneration}

Regeneration reflects an organization's ability to learn from earlier experience and to use that experience to create innovations and develop their operations. Regeneration reflects an organization's ability to learn from earlier experience and to use that experience to create innovations and develop their operations. Organizations need to be tolerant of the mistakes that will occur and allow for recovery and learning from failures (Wan et al., 2005; Lawson and Samson, 2001) to achieve higher innovation capability. It has been suggested that important issues for innovation are the belief that innovation is important, willingness to take risks, and willingness to exchange ideas (Wan et al. 2005). In addition, mutual trust and respect create an atmosphere that encourages individuals to try new ideas without fear of failure and its consequences (Lampikoski and Emden, 1999; Wan et al., 2005).

\section{Individual activity}

Employees' individual innovation capability and activity is needed to form the organization's overall innovation capability, which forms the employee activity aspect. According to Hotho and Champion (2011) the source of innovation resides in the creativity and innovator capability of people. People who have creativity and intrinsic motivation (as well as skills) for their work will be favorable for creating a work environment that supports the creation of innovations. A study of Dixit and Nanda (2011) shows that the motivation of the employees is an important factor in a creative organization. Creative thinking includes the following: the individual has new perspectives on problems, is willing to take risks, and has tolerance for ambiguity (Amabile, 1997). According to Calantone et al. (2002), for effective innovation, established norms, practices, and beliefs may have to be challenged. So, as business realities change, the employees' behavior and actions need to be adjusted accordingly (Dobni, 2008).

\subsection{The research framework}

The purpose of this study is to explore the impact of innovation capability on firm performance within the context of SMEs. The theoretical review discussed above lead to the research framework presented in Figure 1. 
Saunila, M. (2014). Innovation capability for SME success: perspectives of financial and operational performance. Journal of Advances in Management Research, 11(2), 163-175.

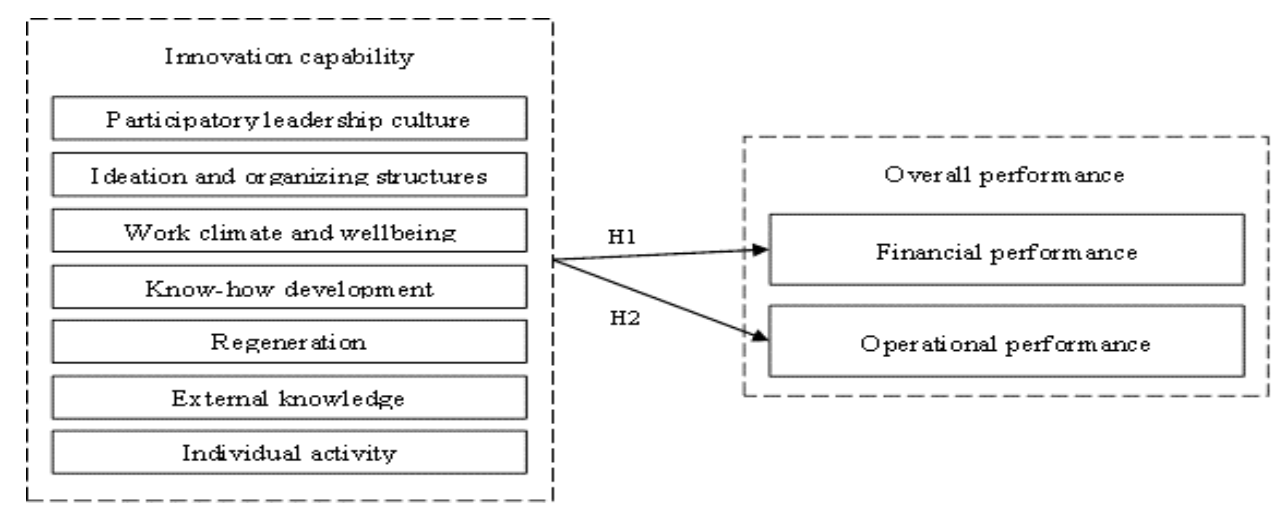

Figure 1 Research framework and hypotheses.

As mentioned earlier, the aim of this study is to examine the relationship between innovation capability and firm performance. Innovation capability has been defined via aspects influencing an organization's capability to manage innovation. These aspects include participatory leadership culture, ideation and organizing structures, work climate and wellbeing, know-how development, regeneration, external knowledge, and individual activity. In this research, a firm's performance is divided into two main areas: operational performance and financial performance. Financial performance is related to the results (profitability, etc.) and operational performance to the determinants of the results (productivity, quality, etc.). Both innovation and innovation capability are defined as antecedents of performance. The basis of the framework is the idea that firm has to concentrate on developing the seven aspects of innovation capability in order to achieve higher financial and operational performance. In order to reach the research aim, two hypotheses were developed. The hypotheses are as follows:

Hypothesis 1: The higher the firm's innovation capability, the greater the firm's financial performance

Hypothesis 2: The higher the firm's innovation capability, the greater the firm's operational performance

\section{Methods}

\subsection{Questionnaire development}

The approach of this study is quantitative. The questionnaire developed for the study consists of two major parts. The first part comprises 30 items measuring different issues related to innovation capability, divided into seven subcategories. The second part comprises 2 items measuring the performance. The items for the questionnaire were operationalized on the basis of a literature review. To maximize the validity and reliability of the construct, existing measurements that had been empirically tested were utilized when possible. New items were built on the basis of previous literature. The items were reviewed and revised with a group of 
Saunila, M. (2014). Innovation capability for SME success: perspectives of financial and operational performance. Journal of Advances in Management Research, 11(2), 163-175.

researchers. The researchers were asked to critically analyze each of the items with respect to the concept it was intended to measure, on the appropriateness of each item, easiness of comprehension, and possible improvements in wording. This resulted in minor changes to the presentation of the questionnaire.

\subsection{Measures}

The independent variables of the study are participatory leadership culture, ideation and organizing structures, work climate and wellbeing, know-how development, regeneration, external knowledge, and individual activity. Each of these variables was measured by a fivepoint Likert-type scale, ranging from 1 (strongly disagree) to 5 (strongly agree). A neutral response "neither disagree nor agree", was adopted to reduce uninformed responses. Each of the independent variables was measured using 3-6 items. When possible, validated measures reported in previous research were used. When the items had to be modified, the items were derived from the literature. The study follows items modified from studies by Hurt et al. (1977), Samson and Terziovski (1999), Tang (1999), Calantone et al. (2002), Guan and Ma (2003), Otala (2003), Wang and Ahmed (2004), Martensen et al.(2007), Dobni (2008), and Kallio et al. (2012).

The dependent variable, firm performance, was measured by two items. According to Bueno et al. (2010) the literature has widely established that there is a high correlation between objective and subjective data on performance, and therefore both are valid when calculating a firm's performance. In this study the subjective perceptions of the informants were used to measure the performance of the companies. Informants were asked to evaluate both the financial and operational (productivity, quality etc.) performance of the company within the past three years on a scale of 1 (weak) to 4 (excellent).

\subsection{Data}

The data used to test the hypotheses was gathered from Finnish SMEs with a web-based questionnaire. SMEs with less than 10 employees were excluded from the sample. The sample covered 2400 SMEs employing 11-249 persons and having a revenue of 2-50 Meuro. The sample was randomly selected. A representative of both management and employees received an invitation to participate in the study. Thus, 4800 questionnaires were sent. A total of 4050 questionnaires reached the informants, while 750 questionnaires were returned to the researchers with return to sender (RTS) messages, indicating that the addresses were no longer valid. The delivery of the questionnaire was conducted in four waves. One week after the first mailing of the questionnaire, reminder questionnaires were sent out. The remaining two reminders were sent a week after the previous reminder. This process resulted in a total of 311 responses, and after discounting the number of RTS mails, the final response rate accounted for 7.68 per cent. 
Saunila, M. (2014). Innovation capability for SME success: perspectives of financial and operational performance. Journal of Advances in Management Research, 11(2), 163-175.

To check the non-response bias, an analysis of variance (ANOVA) test was performed. The informants were divided into four groups: the first informants, the first follow-ups, the second follow-ups and the third follow-ups. The results of the ANOVA test revealed that there was no significant difference (at the 5 per cent significance level) between the four groups. Therefore, it can be assumed that the responses reflect the whole sample well.

Table 1. Background information of the informants

\begin{tabular}{llll}
\hline & & $n$ & $\%$ \\
\hline Revenue (Meuro) & $2-5$ & 141 & 45.3 \\
& $5-20$ & 135 & 43.4 \\
No of employees & $20-50$ & 35 & 11.3 \\
& $10-49$ & 224 & 72.0 \\
Industry & $50-249$ & 87 & 28.0 \\
& Industrial & 145 & 46.6 \\
Organizational & Service & 159 & 51.1 \\
position & No response & 7 & 2.3 \\
& Executive & 222 & 71.4 \\
& & & \\
& White-collar worker & 68 & 21.9 \\
& Blue-collar worker & 12 & 3.9 \\
& No response & 9 & 2.9 \\
\hline
\end{tabular}

\section{Results}

The items, factor loadings, and reliability statistics are presented in the Appendix. To assess the construct validity of the measurement scales, Factor Analysis (FA) was performed. The seven scales were subjected to principal component analysis to test the unidimensionality of the constructs and to eliminate unreliable items. One item was excluded, because it loaded alone among other items into one factor. As shown, the results of the FA suggest that the standardized loadings are highly significant for all the remaining items (the loadings vary from 0.484 to 0.869 ), suggesting that the underlying constructs are valid.

To test the reliability of the results, a Cronbach's alpha test was performed. The alpha value of six factors, as shown in Appendix, are greater than 0.60. In one factor (individual activity) the alpha value is less than 0.50 , which indicates that the reliability of the factor can be questioned, and therefore the results concerning the factor should be handled circumspectly. The overall alpha value of the remaining 29 items is 0.903 . The overall reliability of the construct is therefore supported. In order to assess the extent of multicollinearity, the variance inflation factor (VIF) was computed. The VIFs ranged from 1.015 to 1.382 , which are significantly below the cut-off value of 10, and therefore it is suggested that multicollinearity do not cause problems.

The hypotheses were tested by using the linear regression method. The analyses were conducted on together in all innovation capability aspects and separately to financial and 
Saunila, M. (2014). Innovation capability for SME success: perspectives of financial and operational performance. Journal of Advances in Management Research, 11(2), 163-175.

operational performance. Three control variables that might affect the relationship between firm innovation capability and performance were included: the industry and firm size (measured by both revenue and number of employees). A dummy variable was used for the industry, divided into manufacturing and service industries. The results reported in Table 2 support the hypotheses. Both models are significant. Innovation capability is significantly and positively related to financial and operational performance.

Table 2. Regression results of perceived financial and operational performance

\begin{tabular}{|c|c|c|c|c|}
\hline \multirow[t]{2}{*}{ Dependent variable } & \multicolumn{2}{|c|}{ Perceived financial performance } & \multicolumn{2}{|c|}{$\begin{array}{l}\text { Perceived operational } \\
\text { performance }\end{array}$} \\
\hline & Beta & $t$ & Beta & $t$ \\
\hline \multicolumn{5}{|l|}{ Independent variables } \\
\hline External knowledge & 0.007 & 0.110 & -0.075 & -1.235 \\
\hline Work climate and wellbeing & -0.059 & -0.754 & 0.133 & 1.876 \\
\hline $\begin{array}{l}\text { Ideation and organizing } \\
\text { structures }\end{array}$ & 0.266 & $3.695 * * *$ & 0.232 & $3.947 * * *$ \\
\hline Regeneration & 0.014 & 0.197 & -0.001 & -0.022 \\
\hline Participatory leadership culture & -0.249 & $-3.476 * * *$ & -0.054 & -0.758 \\
\hline Individual activity & 0.031 & 0.490 & 0.077 & 1.265 \\
\hline Know-how development & 0.139 & $2.058^{*}$ & 0.060 & 0.901 \\
\hline \multicolumn{5}{|l|}{ Control variables } \\
\hline Revenue & 0.196 & $2.942 * *$ & 0.112 & 1.923 \\
\hline Number of employees & -0.218 & $-3.285 * * *$ & -0.082 & -1.404 \\
\hline Industry & 0.101 & 1.712 & 0.013 & 0.214 \\
\hline $\mathrm{F}$ & & $8.258 * * *$ & & $15.578 * * *$ \\
\hline $\mathrm{R}$ & & 0.362 & & 0.232 \\
\hline $\mathrm{R}^{2}$ & & 0.131 & & 0.054 \\
\hline Adjusted $\mathrm{R}^{2}$ & & 0.115 & & 0.050 \\
\hline
\end{tabular}

Sign. ${ }^{* *} \leq 0.001,{ }^{* *} 0.001<\mathrm{p} \leq 0.01, * 0.01<\mathrm{p} \leq 0.05$

The regression model investigating the relationship between innovation capability and financial performance is significant $\left(F=8.258\right.$, Sig. 0.000). The adjusted $R^{2}$ is 0.115 , which shows that the model has a 11.5 per cent of the total variation in the dependent variable (financial performance). The standardized beta of ideation and organizing structures is 0.266 (Sig. 0.000), participatory leadership culture -0.249 (Sig. 0.001), and know-how development 0.139 (Sig. 0.041). The results indicate that the three aspects of innovation capability tends to be related to the financial performance, which is consistent with the hypothesis. The size of the company (measured by revenue) seems to be related to financial performance. The larger the firm, the better the respondent perceive it to be performing. Number of the employees seems to be negatively related to financial performance. Firms with fewer emloyees seem to perceive their financial performance higher.

The regression model investigating the relationship between innovation capability and operational performance is significant $\left(F=15.578\right.$, Sig. 0.000). However, the adjusted $\mathrm{R}^{2}$ indicates that only 5.0 per cent of the variation in operational performance is explained by the model. The standardized beta of ideation and organizing structures is 0.232 and significant 
Saunila, M. (2014). Innovation capability for SME success: perspectives of financial and operational performance. Journal of Advances in Management Research, 11(2), 163-175.

(Sig. 0.000). The results indicate that ideation and organizing structures tends to be positively related to operational performance. This is consistent with the hypothesis. No significant differences were found in control variables as regards the overall operational performance.

To check for robustness of the results, the data was randomly divided into two equal groups. After that the same analyses were made to check if they provide inconsistent results. The same aspects of innovation capability were significant in the models than when the analyses were made with the whole data. Thus, the results are valid. The results of regression models examining the connection between innovation capability and firm's financial and operational performance suggest that performance of an organization can be affected by aspects of innovation capability.

\section{Discussion and conclusions}

Despite the literature suggesting a positive relationship between organizational innovation capability and performance, few studies analyze the relationship taking into account the various aspects of innovation capability in a single model. In addition, previous research has concentrated on studying the effects of different types of innovations and organizational performance. This study goes a step further by studying the effects of firm's capability to produce innovations on organizational performance. The findings showed that three aspects of innovation capability, namely ideation and organizing structures, participatory leadership culture, and know-how development, are connected to different aspects of firm performance. Surprisingly, the aspects of innovation capability were found to be more influential to the financial performance than operational performance.

According to the results of the study ideation and organizing structures are positively related to financial and operational performance. This is in line with the study of Jiménez-Jiménez and Sanz-Valle (2011) which show that organizational routines that help firms to conduct their activities more efficiently and, therefore, obtain better performance. When the structures and ways of working function well, employees have time to concentrate on completing their tasks. This means that management should organize the work in a way that it releases employees from the extra pressure concerning the ways of working. It means that managers should not be too tied in the daily routines, because it can result neglecting their main task, which is managing the company in relation to its strategic objectives. This conclusion is supported by the results of this study. The previous study of Zhu et al. (2005) concludes that leadership is one of the key driving forces for improving firm performance. However, in this study the effect was found to be negative between a participatory leadership culture and perceived performance. If the managers of SMEs, which usually have low organizational hierarchy levels, concentrate too much on the operative level actions, they may ignore their primary task: management of the firm. On the other hand, tight participation of the managers in operational activities may decrease employee idea generation and creativity. These two reasons may thus explain the 
negative relationship between a participatory leadership culture and financial performance. The perception may be caused by managers' personalities, formal structures, or organizational cultures that do not favor participation. Despite participating in the daily routines to some extent, the leaders should not neglect the management part.

This study contains some interesting findings that would provide good starting point for further studies. First, the relationship between a participatory leadership culture and financial performance was found to be negative. This result is somewhat contrary to previous research. Thus, the issue needs more research. Second, it is not clear whether and to what extent each of the innovation capability determinants correlate with each of the overall performance constructs (productivity, profitability etc.). This should be a subject of future studies. Third, the study did not clarify how a linkage between the aspects of innovation capability and firm performance can be made. Further studies are needed to formulate measures for both aspects of innovation capability and firm performance so that the causal relationships can be identified. Fourth, there were four aspects of innovation capability that were not found to have a direct relationship with firm performance. Thus, there may be other aspects that moderate the relationship. Further studies should identify these aspects, so that the path from the aspects of innovation capability and firm performance could be defined more exactly.

\section{References}

Amabile, T.M. (1997) "Motivating creativity in organizations: On doing what you love and loving what you do", California management review, 40 (1): 39-58.

Armbruster, H., Bikfalvi, A., Kinkel, S. and Lay, G. (2008) "Organizational innovation: The challenge of measuring non-technical innovation in large-scale surveys", Technovation, 28 (10): 644-657.

Bessant, J. (2003) High-Involvement Innovation: Building and Sustaining Competitive Advantage Trough Continuous Change, John Wiley \& Sons, Chichester.

Bowen, F.E., Rostami, M. and Steel, P. (2010) "Timing is everything: A meta-analysis of the relationships between organizational performance and innovation", Journal of Business Research, 63 (11): 1179-1185.

Bueno, E., Aragón, J.A., Salmador, M.P. and García, V.J. (2010) “Tangible slack versus intangible resources: the influence of technology slack and tacit knowledge on the capability of organisational learning to generate innovation and performance", International Journal of Technology Management, 49 (4): 314-337. 
Saunila, M. (2014). Innovation capability for SME success: perspectives of financial and operational performance. Journal of Advances in Management Research, 11(2), 163-175.

Cainelli, G., Evangelista, R. and Savona, M. (2004) "The impact of innovation on economic performance in services", Service Industries Journal, 24 (1): 116-130.

Calantone, R.J., Cavusgil S.T. and Zhao, Y. (2002) "Learning orientation, firm innovation capability, and firm performance", Industrial Marketing Management, 31 (6): 515-524.

Cavusgil, S.T., Calantone, R.J. and Zhao, Y. (2003) "Tacit knowledge transfer and firm innovation capability", Journal of Business \& Industrial Marketing, 18 (1): 6-21.

Colarelli O'Connor, G. (2008) "Major Innovation as a Dynamic Capability: A Systems Approach", Journal of Product Innovation Management, 25 (4): 313-330.

Dixit, G.K. and Nanda, T. (2011) Strategic Alignment of Organizational Culture and Climate for Stimulating Innovation in SMEs", International Journal of Innovation, Management and Technology, 2 (1): 77-85.

Dobni, C.B. (2010) "The relationship between an innovation orientation and competitive strategy", International Journal of Innovation Management, 14 (2): 331-357.

Dobni, C.B. (2008) "Measuring innovation culture in organizations, The development of a generalized innovation culture construct using exploratory factor analysis", European Journal of Innovation Management, 11 (4): 539-559.

Francis, D. and Bessant, J. (2005) "Targeting innovation and implications for capability development", Technovation, 25 (3): 171-183.

Gopalakrishnan, S. (2000) "Unraveling the links between dimensions of innovation and organizational performance", The Journal of High Technology Management Research, 11 (1): $137-153$.

Guan, J. and Ma, N. (2003) "Innovative capability and export performance of Chinese firms", Technovation, 23 (9): 737-747.

Hashi, I. and Stojcic, N. (2013) "The impact of innovation activities on firm performance using a multi-stage model: Evidence from the Community Innovation Survey 4", Research Policy, 42 (2): 353-366.

Hotho, S. and Champion, K. (2011) "Small businesses in the new creative industries: innovation as a people management challenge", Management Decision, 49 (1): 29-54. 
Saunila, M. (2014). Innovation capability for SME success: perspectives of financial and operational performance. Journal of Advances in Management Research, 11(2), 163-175.

Hurt, T.H., Joseph, K. and Cook, C.D. (1977) "Scales for the measurement of innovativeness", Human Communication Research, 4 (1): 58-65.

Ibrahim, A.R., Zolait, A.H.S., Subramanian, S. and Ashtiani, A.V. (2009) "Organizational Innovative Capabilities: An Empirical Study of Malaysian Firms", Journal of Innovation and Business Best Practices, 1 (2): 9-18.

Jiménez-Jiménez, D. and Sanz-Valle, R. (2011) "Innovation, organizational learning, and performance", Journal of Business Research, 64 (4): 408-417.

Kallio, A., Kujansivu, P., Parjanen, S., (2012) "Locating the loopholes of innovation capability before launching development project", Interdisciplinary Journal of Information, Knowledge, and Management, 7: 21-38.

Keskin, H. (2006) "Market orientation, learning orientation, and innovation capabilities in SMEs - An extended model", European Journal of Innovation Management, 9 (4): 396-417.

Lampikoski, K. and Emden, J.B. (1999) Managing innovatively: exploit creative resources, WSOY, Porvoo.

Lawson, B. and Samson, D. (2001) "Developing innovation capability in organisations: a dynamic capabilities approach", International Journal of Innovation Management, 5 (3): 377400 .

Martensen, A., Dahlgaard, J.J., Park-Dahlgaard, S.M. and Grønholdt, L. (2007) "Measuring and diagnosing innovation excellence - simple contra advanced approaches: a Danish study", Measuring Business Excellence, 11 (4): 51-65.

Martínez-Román, J.A., Gamero, J. and Tamayo, J.A. (2011) “Analysis of innovation in SMEs using an innovative capability-based non-linear model: A study in the province of Seville (Spain)", Technovation, 31 (9): 459-475.

McMurray, A.J., Pirola-Merlo, A., Sarros, J.C. and Islam, M.M. (2010) "Leadership, climate, psychological capital, commitment, and wellbeing in a non-profit organization”, Leadership \& Organization Development Journal, 31 (5): 436-457.

Neely, A., Filippini, R., Forza, C., Vinelli, A., Hii, J. (2001) "A framework for analysing business performance, firm innovation and related contextual factors: perceptions of managers and policy makers in two European regions", Integrated Manufacturing Systems, 12 (2): 114 124. 
Saunila, M. (2014). Innovation capability for SME success: perspectives of financial and operational performance. Journal of Advances in Management Research, 11(2), 163-175.

Otala, L. (2003) Welfare to workplace - outcome to the action, WSOY, Helsinki. (in Finnish)

Paalanen, A., Kujansivu, P., Parjanen, S. (2009) "Measuring the effects of an innovationfocused intervention", In the Proceedings of the XX ISPIM Future of Innovation Conference, June 2009, Vienna, Austria.

Perdomo-Ortiz, J., González-Benitoa, J. and Galende, J. (2006) "Total quality management as a forerunner of business innovation capability", Technovation, 26 (10): 1170-1185.

Prajogo, D.I. and Ahmed, P.K. (2006) "Relationships between innovation stimulus, innovation capacity, and innovation performance”, R\&D Management, 36 (5): 499-515.

Romijn, H., Albaladejo, M. (2002) "Determinants of innovation capability in small electronics and software firms in southeast England”, Research Policy, 31 (7): 1053-1067.

Rosenbusch, N., Brinckmann, J. and Bausch, A. (2011) "Is innovation always beneficial? A meta-analysis of the relationship between innovation and performance in SMEs", Journal of Business Venturing, 26 (4): 441-457.

Samson, D. and Terziovski, M. (1999) "The relationship between total quality management practices and operational performance", Journal of Operations Management, 17 (4): 393-409.

Saunila, M. and Ukko, J. (2011) "Intangible aspects of organizational innovation capability in Finnish SMEs", In the proceedings of 6th International Forum on Knowledge Asset Dynamics, June 2011, Tampere, Finland.

Sen, F.K. and Egelhoff, W.G. (2000) "Innovative capabilities of a firm and the use of technical alliances”, IEEE Transactions on Engineering Management, 47 (2): 174-183.

Skarzynski, P. and Gibson, R. (2008) Innovation to the Core: a blueprint for transforming the way your company innovates, Harvard Business School Press, Boston.

Smith, M., Busi, M., Ball, P. and van der Meer, R. (2008) "Factors influencing an organisation's ability to manage innovation: a structured literature review and conceptual model", International Journal of Innovation Management, 12 (4): 655-676.

Swink, M. (2006) "Building Collaborative Innovation Capability", Research-Technology Management, 49 (2): 37-47.

Subramanian, A., Nilakanta, S. (1996) "Organizational Innovativeness: Exploring the Relation-ship Between Organizational Determinants of Innovation, Types of Innovations, and 
Saunila, M. (2014). Innovation capability for SME success: perspectives of financial and operational performance. Journal of Advances in Management Research, 11(2), 163-175.

Measures of Organizational Performance", International Journal of Management Science, 24 (6): 631-647.

Tang, H.K. (1999) “An inventory of organizational innovativeness", Technovation, 19 (1): 4151.

Tidd, J., Bessant, J., Pavitt, K. (2005) Managing innovation: Integrating Technological, Market and Organizational Change, John Wiley \& Sons, West Sussex, England.

Tidd, J. (2001) "Innovation management in context: environment, organization and performance", International Journal of Management Reviews, 3 (3): 169-183.

Varadarajan, R. (2009) "Fortune at the bottom of the innovation pyramid: The strategic logic of incremental innovations", Business Horizon, 52 (1): 21-29.

Viitala, R. (2005) Lead expertise! Leading the expertise from theory to practice, Infoviestintä Oy, Helsinki.

Wan, D., Ong, C.H. and Lee, F. (2005) "Determinants of firm innovation in Singapore", Technovation, 25 (3): 261-68.

Wang, C.L. and Ahmed P.K. (2004) "The development and validation of the organizational innovativeness construct using confirmatory factor analysis", European Journal of Innovation Management, 7 (4): 303-313.

Yang, C.C., Marlow, P.B. and Lu, C-S. (2009) "Assessing resources, logistics service capabilities, innovation capabilities and the performance of container shipping services in Taiwan”, International Journal of Production Economics, 122 (1): 4-20. 
Saunila, M. (2014). Innovation capability for SME success: perspectives of financial and operational performance. Journal of Advances in Management Research, 11(2), 163-175.

\section{Appendix.}

Means and standard deviations of the items, and parameter estimates for measurement relations

\begin{tabular}{|c|c|c|c|c|}
\hline Item & Mean & $\begin{array}{l}\text { Std. } \\
\text { Dev. }\end{array}$ & $\begin{array}{l}\text { St. } \\
\text { loadings }\end{array}$ & $\begin{array}{l}\text { Cronbach's } \\
\text { alpha }\end{array}$ \\
\hline Participatory leadership culture & 3.65 & 0.613 & & 0.803 \\
\hline 12 The managers encourage initiatives & 3.72 & 0.912 & 0.769 & \\
\hline 13 The managers give positive feedback & 3.60 & 0.844 & 0.749 & \\
\hline $\begin{array}{l}14 \text { The managers pass employees' ideas to the upper } \\
\text { levels of the organization }\end{array}$ & 3.67 & 0.864 & 0.747 & \\
\hline 15 The managers participate in ideation and development & 4.02 & 0.781 & 0.776 & \\
\hline 23 There are practices for transferring tacit knowledge & 3.12 & 1.055 & 0.573 & \\
\hline 27 The employees are appreciated for their work & 3.80 & 0.706 & 0.686 & \\
\hline Ideation and organizing structures & 3.45 & 0.628 & & 0.708 \\
\hline $\begin{array}{l}5 \text { We have a clear way of processing and developing } \\
\text { ideas }\end{array}$ & 3.32 & 1.032 & 0.772 & \\
\hline 6 The employees get feedback for their ideas & 3.82 & 0.828 & 0.714 & \\
\hline 7 Our reward system encourages ideating & 2.86 & 1.062 & 0.689 & \\
\hline $\begin{array}{l}20 \text { We have instructions and responsible persons for } \\
\text { work orientation }\end{array}$ & 3.66 & 1.061 & 0.553 & \\
\hline 28 The number of working tasks is suitable & 3.29 & 1.015 & 0.484 & \\
\hline $\begin{array}{l}29 \text { The quality, demands and responsibility of tasks are } \\
\text { suitable }\end{array}$ & 3.73 & 0.807 & 0.624 & \\
\hline Work climate and wellbeing & 3.94 & 0.597 & & 0.786 \\
\hline 4 Co-operation works well in our organization & 3.84 & 0.852 & 0.704 & \\
\hline 11 The employees have the courage to disagree & 3.97 & 0.820 & 0.742 & \\
\hline 21 The employees are encouraged to be multi-skilled & 4.03 & 0.740 & 0.713 & \\
\hline 25 The employees prosper in our organization & 4.00 & 0.687 & 0.707 & \\
\hline 26 The employees are treated equally & 3.87 & 0.915 & 0.807 & \\
\hline Know-how development & 3.76 & 0.783 & & 0.738 \\
\hline 19 All employees have a possibility for education & 3.72 & 1.072 & 0.778 & \\
\hline $\begin{array}{l}22 \text { Voluntary learning and development of expertise are } \\
\text { supported in our organization }\end{array}$ & 3.78 & 0.881 & 0.819 & \\
\hline $\begin{array}{l}24 \text { In our organization, learning is an investment, not an } \\
\text { expense }\end{array}$ & 3.80 & 0.924 & 0.843 & \\
\hline Regeneration & 3.80 & 0.784 & & 0.766 \\
\hline 8 Our organization seeks new ways of action actively & 3.72 & 1.040 & 0.813 & \\
\hline $\begin{array}{l}9 \text { Our organization has the courage to try new ways of } \\
\text { action }\end{array}$ & 3.83 & 0.941 & 0.869 & \\
\hline $\begin{array}{l}10 \text { When experimenting with new ways of action, } \\
\text { mistakes are allowed }\end{array}$ & 3.86 & 0.860 & 0.799 & \\
\hline External knowledge & 3.96 & 0.733 & & 0.625 \\
\hline $\begin{array}{l}1 \text { My work community encourages gaining knowledge } \\
\text { through external contacts }\end{array}$ & 4.00 & 1.042 & 0.742 & \\
\hline $\begin{array}{l}2 \text { We have developed our ways of action by comparing } \\
\text { our operations to other organizations }\end{array}$ & 3.75 & 0.985 & 0.797 & \\
\hline $\begin{array}{l}3 \text { We develop our actions together with our stakeholders } \\
\text { (customers etc.) }\end{array}$ & 4.13 & 0.864 & 0.731 & \\
\hline Individual activity & 3.59 & 0.612 & & 0.486 \\
\hline $\begin{array}{l}16 \text { The employees are willing to participate in } \\
\text { development }\end{array}$ & 3.70 & 0.830 & 0.758 & \\
\hline $\begin{array}{l}17 \text { It is easy for the employees to adopt new ways of } \\
\text { action }\end{array}$ & 3.12 & 0.959 & 0.764 & \\
\hline $\begin{array}{l}18 \text { The employees know how to be critical towards } \\
\text { current ways of action when needed }\end{array}$ & 3.97 & 0.734 & 0.570 & \\
\hline
\end{tabular}

